\title{
Reply to Dr. Götz and colleagues
}

\author{
Luca Mascitelli · Francesca Pezzetta • \\ Mark R. Goldstein
}

Received: 9 June 2009/Accepted: 9 June 2009/Published online: 23 June 2009

(c) Birkhäuser Verlag, Basel/Switzerland 2009

We agree with Götz and colleagues that a similar role for iron in type 2 diabetes mellitus and Alzheimer's disease could also extend to a general phenomenon of altered biometal stasis. Indeed, it has been shown that copper, iron and zinc are increased in senile plaques in $\mathrm{AD}$ [1]. In view of reports of increased aggregation of amyloid $\beta$ peptide in vitro in the presence of these elements, it is possible that they play a role in the increased aggregation of amyloid $\beta$ peptide in senile plaque formation in $\mathrm{AD}$ brain, thus enhancing the genesis of senile plaques. The increase in iron and copper could also serve as a catalyst for increased free radical formation which might be important in the toxicity of amyloid $\beta$ peptide.
However, among the strategies aimed at biometals depletion, phlebotomy, which effectively reduces body iron stores, is the safest and easiest way to reduce a biometal [2].

\section{References}

1. Lovell MA, Robertson JD, Teesdale WJ, Campbell JL, Markesbery WR (1998) Copper, iron and zinc in Alzheimer's disease senile plaques. J Neurol Sci 158:47-52

2. Dwyer BE, Zacharski LR, Balestra DJ, Lerner AJ, Perry G, Zhu X, Smith MA (2009) Getting the iron out: phlebotomy for Alzheimer's disease? Med Hypotheses 72:504-509
L. Mascitelli $(\bowtie)$

Medical Service, Comando Brigata alpina "Julia", Udine, Italy

e-mail: lumasci@libero.it

\section{F. Pezzetta}

Cardiology Service, Ospedale di Tolmezzo, Tolmezzo, Italy

M. R. Goldstein

Fountain Medical Court, Bonita Springs, FL, USA 